\title{
PERFORMANCE OF SUBSTRATE REINFORCED CONCRETE SLABS WITH GEOPOLYMER CONCRETE OVERLAY
}

\author{
Mariam F. Ghazy ${ }^{1}$, Metwally A. Abd elaty ${ }^{* 1}$, Mohamed H. Taman ${ }^{2}$ and Nesreen A. Nasr ${ }^{3}$ \\ ${ }^{1}$ Prof, Structural Engineering Dept., Faculty of Engineering, Tanta University, Tanta, Egypt \\ E mail: Mariam.ghazy@f-eng.tanta.edu.eg \& *E mail: Metwali.abdelatty@f-eng.tanta.edu.eg \\ ${ }^{2}$ Assoc. Prof. Structural Engineering Dept., Faculty of Engineering, Tanta University, Tanta, Egypt \\ E mail: Mohamed.taman@f-eng.tanta.edu.eg \\ ${ }^{3}$ Demonstrator, Tanta Higher Institute for Engineering \& Technology, B. Sc. Civil Engineering, \\ Tanta University, Tanta, Egypt \\ Email: Nesreen_nasr@yahoo.com
}

\begin{abstract}
Geopolymer concrete (GPC) has been used increasingly in recent years and has been applied to various structural components. Considerable interest has been developed in using geopolymer in concrete to increase the load carrying capacity of the structural members in service. It has been used recently to increase the flexural capacity of concrete slabs by applying overlay layer of GPC onto an existing slab, a technique known as cement base bonded overlay. The objective of this research is the investigation of the flexural behavior of substrate cement reinforced concrete (RC) slabs with a GPC overlay. Seven RC slabs with 300 x 1700 x $100 \mathrm{~mm}, 33 \mathrm{MPa}$ compressive strength after 28 days and reinforced with steel with a diameter of $8 \mathrm{~mm}$. Because the performance of these composite slabs depends on the bonding between the substrate and overlay concrete, six different techniques were used for preparing the RC substrate surfaces including, (as smooth as cast (AS), carving $2 \mathrm{~mm}$ width and $1 \mathrm{~mm}$ deep (Carv), dowels $8 \mathrm{~mm} \mathrm{Z}$ section (DZ), painting with epoxy resin on the surface (ER), surface roughened by a stiff brush in both the transverse and longitudinal directions (T\&L) D and surface roughened in the transverse directions by a stiff brush (TD). The evaluated properties were load deflection relationship, strain distribution curves and the interface slip.

Based on the experimental tests, ductile performance of slab depends not only on adding GPC to the topping but mainly on the type of interface roughness. Moreover, the ductility ratio may be arranged in desponding order as (TD), (T\&L) D, (ER), (Carv), (DZ) and (AS). The biggest slip happened for slab control at $0.25 \mathrm{~mm}$, signifying poor bonding strength at the interface. Slab (L\&T) D, with zero $\mathrm{mm}$ of slippage, showed the best interface slip.
\end{abstract}

Keywords: Geopolymer concrete, Cement concrete, Substrate surface preparation, strain distribution, Interface slip.

\section{INTRODUCTION}

Environmentally stressful repair materials with reduced carbon $\mathrm{CO}_{2}$ footprint have been in great demand by the construction industry worldwide. Geopolymer binders are preferred because the $\mathrm{CO}_{2}$ footprint generated by concretes comprising geopolymer binders and $100 \%$ OPC concrete were compared. The $\mathrm{CO}_{2}$ footprint of geopolymer concrete is approximately $9 \%$ less than comparable concrete containing $100 \%$ OPC binder [1]. The effect of surface preparation on the bond between repair materials and concrete substrate was studied. It was found that the bond strength of repair materials can be considerably increased with surface roughening [2].

The influence of concrete substrate preparation overlay bond strength was studied. This study recognized that a saturated, surface-dry substrate concrete has usually no useful influence on overlay bond strength. A lot of cases, the use of substrate surfaces prepared to what is generally measured the optimum moisture condition resulted in considerably lower bond strength, compared with nonpreconditioned substratesn [3].

The effect of sodium hydroxide and sodium silicate solutions on bond shear bond strength of flyash granulated blast furnace slag geopolymer was studied. It is originated that the bond strength of geopolymer concrete depends on the type of alkaline activator solution and compressive strength of geopolymer concrete. It is also showed that the reaction product of geopolymer depends on source of material and alkali activator solution [4].

The bond strength of geopolymers at ambient and elevated temperatures showed that geopolymers 
show lower bond strength than that of epoxy resin at room temperature, however geopolymers keep much higher bond strength in 100-300 0C. Adding of small amount of short carbon fibers in metakaolin or flyash will not advance the bond strength of geopolymers at ambient temperature, but really advance bond strength at $100-300{ }^{\circ} \mathrm{C}$ through crack control mechanism [5].

The bond strength of reinforcing steel embedded in flyash based geopolymer concrete was studied. Pull out test was used to determine the bond strength of geopolymer concrete and OPC concrete with

\section{Experimental Program}

The objective of this paper was to investigate the effect of different types of roughness on bond strength between substrate RC and GPC overlay using local materials. GPC mix cast with molarities $16 \mathrm{M}$, sand $(\mathrm{S})$ to coarse aggregate $(\mathrm{CA})$ ratio $(1: 1.65)$ and sodium silicate (NS) to sodium hydroxide $(\mathrm{NH})$ ratio (2.5:1). The substrate surface prepared with different techniques such as smooth as cast, carving $2 \mathrm{~mm}$ width and $1 \mathrm{~mm}$ deep, dowels $8 \mathrm{~mm} \mathrm{Z}$ section, painting with epoxy resin on the surface, surface roughened in both the longitudinal and transverse directions by a stiff brush and surface roughened in the transverse directions by a stiff brush.

\subsection{Materials specification}

The materials that are used in the study are:

1-Cement- Portland cement (C) CEM I $42.5 \mathrm{~N}$ was used for the production of cement concrete. The cement met the requirements of (EN 196-1:2016) [7] and ES 4756-1 [8] with fineness $3500 \mathrm{~cm}^{2} / \mathrm{g}$.

2-Fly ash-Class F (ASTM C 618-08a) (FA) was used for the production of GPC specimens, Table (1) gives the chemical composition of the cement and the class F fly ash were determined by X-Ray Fluorescence (XRF) analysis.

3- Fine aggregates- Medium well-graded sand of specific gravity of 2.6 was used for all specimens and satisfied the requirements of ECP 203-2007[9] and ASTM C33 / C33M - 18[10].

4- Coarse aggregates- Crushed lime stone with maximum particle size of $10 \mathrm{~mm}$ and specific gravity of 2.55 was used as coarse aggregate (CA) for all

specimens and was complied with the limits of ECP 203-2007 [9].

5-Solution- The alkaline activator was a mixture of chemical grade $\mathrm{NH}$ flakes with $98-99 \%$ purity solution and NS (14.7\% Na2O, 29.4\% $\mathrm{SiO} 2$ and $55.9 \%$ water by mass).

6-Water- Tap water was used in all concrete specimens and in the curing of specimens which satisfies the requirements of ECP 203-2007 [9].

7- Steel- Mild steel (St. A) of diameters $8 \mathrm{~mm}$ were used as the reinforcement in short and long direction of slab. The properties of the used reinforcements are tabulated in Table 2. reinforcing steel. Geopolymer concrete and OPC concrete shows similar cracking pattern under pull out test. Study also found that bond strength of geopolymer concrete was higher than that of OPC concrete [6].

The aim of this research is to evaluate the flexural performance of substrate concrete slab with geopolymer concrete topping related to different roughnesses of the substrate surface. To examine the composite behavior of the specimens, interface slip was also measured throughout the experiments.

Table (1): Chemical analysis of the used Portland cement and fly ash

\begin{tabular}{|c|c|c|c|}
\hline \multirow[t]{2}{*}{ Oxide } & \multirow{2}{*}{$\begin{array}{l}\text { Portland } \\
\text { cement }\end{array}$} & \multicolumn{2}{|c|}{ Fly ash } \\
\hline & & & $\begin{array}{l}\text { Limits } \\
\text { (ASTM } \\
\text { C618) } \\
\text { class F }\end{array}$ \\
\hline $\begin{array}{l}\text { Silicon dioxide } \\
\left(\mathrm{SiO}_{2}\right)(\%) \text { by } \\
\text { mass }\end{array}$ & 20 & 60.28 & -- \\
\hline $\begin{array}{l}\text { Aluminum } \\
\text { oxide }\left(\mathrm{Al}_{2} \mathrm{O}_{3}\right) \\
(\%) \text { by mass } \\
\end{array}$ & 5.20 & 28.59 & -- \\
\hline $\begin{array}{l}\text { Ferric oxide } \\
\left(\mathrm{Fe}_{2} \mathrm{O}_{3}\right)(\%) \text { by } \\
\text { mass }\end{array}$ & 3.10 & 4.99 & -- \\
\hline $\begin{array}{l}\text { Total } \mathrm{SiO}_{2+} \\
\mathrm{Al}_{2} \mathrm{O}_{3}+\mathrm{Fe}_{2} \mathrm{O}_{3} \\
(\%) \text { by mass }\end{array}$ & 28.3 & 93.86 & $70 \mathrm{~min}$ \\
\hline $\begin{array}{l}\text { Calcium oxide } \\
(\mathrm{CaO})(\%) \text { by } \\
\text { mass }\end{array}$ & 63 & 1.19 & $5.0 \max$ \\
\hline $\begin{array}{l}\text { Phosphorus pent } \\
\text { oxide }\left(\mathrm{P}_{2} \mathrm{O}_{5}\right) \\
(\%) \text { by mass }\end{array}$ & - & 0.52 & $\begin{array}{c}\text { Not } \\
\text { specified }\end{array}$ \\
\hline $\begin{array}{l}\text { Sulphur trioxide } \\
\left(\mathrm{SO}_{3}\right)(\%) \text { by } \\
\text { mass }\end{array}$ & 3.01 & 0.06 & $5.0 \max$ \\
\hline $\begin{array}{l}\text { Potassium oxide } \\
\left(\mathrm{K}_{2} \mathrm{O}\right)(\%) \text { by } \\
\text { mass }\end{array}$ & 0.15 & 1.09 & $\begin{array}{c}\text { Not } \\
\text { specified }\end{array}$ \\
\hline $\begin{array}{l}\text { Titanium } \\
\text { dioxide }\left(\mathrm{TiO}_{2}\right) \\
(\%) \text { by mass }\end{array}$ & - & 2.42 & $\begin{array}{c}\text { Not } \\
\text { specified }\end{array}$ \\
\hline $\begin{array}{l}\text { Sodium oxide } \\
\left(\mathrm{Na}_{2} \mathrm{O}\right)(\%) \text { by } \\
\text { mass }\end{array}$ & 0.44 & 0.01 & $1.50 \max$ \\
\hline $\begin{array}{l}\text { Magnesium } \\
\text { oxide }(\mathrm{MgO}) \\
(\%) \text { by mass } \\
\end{array}$ & - & 0.27 & $\begin{array}{c}\text { Not } \\
\text { specified }\end{array}$ \\
\hline $\begin{array}{l}\text { Loss onIgnition } \\
(\mathrm{LOI})(\%) \text { by } \\
\text { mass }\end{array}$ & 5.10 & 0.58 & $6.0 \max$ \\
\hline
\end{tabular}


Table 2: Mechanical properties of the steel reinforcement of slabs according to tests

\begin{tabular}{|l|c|c|c|c|}
\hline $\begin{array}{c}\text { Steel } \\
\text { type }\end{array}$ & $\begin{array}{c}\text { Diameter } \\
(\mathbf{m m})\end{array}$ & $\begin{array}{c}\text { Yield } \\
\text { stress } \\
(\mathbf{M P a})\end{array}$ & $\begin{array}{c}\text { Tensile } \\
\text { strength } \\
(\mathbf{M P a})\end{array}$ & $\begin{array}{c}\text { Elastic } \\
\text { modulus } \\
(\mathbf{G P a})\end{array}$ \\
\hline St. A & 8 & 290 & 400 & 202 \\
\hline
\end{tabular}

\subsection{Test specimen}

A total of seven specimens, including a control specimen NC/RC (substrate RC with NC overlay) and six GPC/RC (substrate RC with GPC overlay) were cast for this study. The dimensions of substrate layer were $300 \mathrm{~mm}$ in width, $1700 \mathrm{~mm}$ in length and $50 \mathrm{~mm}$ in thickness. Figure 1 shown the details of slab specimens, the substrate slab is lightly reinforced an $8 \mathrm{~mm}$. To cast the overlay, a formwork $300 \mathrm{~mm}$ in width, $1500 \mathrm{~mm}$ in length and $50 \mathrm{~mm}$ in thickness.

\subsection{Specimen preparation, casting and curing}

The proportions of GPC and NC mixes are tabulated in Table 3. Absolute volume design method was used to design these concrete mixes. NC was mixed in a classical procedure where crushed lime stone and sand were mixed first for 2 minutes then cement was added and the dry components were mixed for about 3 minutes to obtain a homogeneous dry mix, then water was added during the mixing process which continued for another 3 minutes or until obtaining a homogeneous mixture. The NC specimens were casted and the substrate concrete surfaces were roughened by different techniques shown in Table 4 and Figure 1. Substrate specimens left at ambient conditions $\left(25 \pm 2{ }^{\circ} \mathrm{C}\right.$, $55 \% \mathrm{RH})$ for 7 days up to casting GPC overlay. Before casting the overlay, the surface of substrate was cleaned of any dust and pre-wet for better bonding between the overlay and substrate member.

For GPC the NH solution was prepared one day before mixing process. Alkaline solution was prepared by mixing the $\mathrm{NH}$ and $\mathrm{NS}$ solutions together and was left in room temperature to cool down prior to mixing with the solids. For this study, the fly ash, coarse and fine aggregates, were first mixed in a dry state in the laboratory mixer for about three minutes. At the end of this mixing, the solution was added into the dry mixture. The mixing continued for another four minutes. Then specimens were lifted in the outdoor condition $\left(25 \pm 2{ }^{\circ} \mathrm{C}\right.$, $55 \% \mathrm{RH})$ for 3 months up to the testing.
The characteristics of the specimens and concrete properties for both the substrate and overlay concrete slab after 28 days were measured. These properties are based on an average of three cubes with dimensions of $100 \mathrm{~mm} \times 100 \mathrm{~mm} \times 100 \mathrm{~mm}$ for measuring compressive strength and bulk density, three cylinders with dimensions of $200 \mathrm{~mm}$ in height and $100 \mathrm{~mm}$ in diameter for measuring splitting tensile strength, and three prisms with dimensions of $500 \mathrm{~mm} \times 100 \mathrm{~mm} \times 100 \mathrm{~mm}$ for measuring flexural strength.

Table 3: Proportions of concrete mixes

\begin{tabular}{|c|c|c|c|c|c|c|l|}
\hline \multirow{2}{*}{ Type } & $\begin{array}{c}\text { Mix } \\
\text { ID }\end{array}$ & M & $\begin{array}{c}\text { NS/ } \\
\text { NH }\end{array}$ & $\begin{array}{c}\text { Sol/ } \\
\text { FA }\end{array}$ & $\begin{array}{l}\text { S / } \\
\text { Agg }\end{array}$ & $\begin{array}{c}\text { CA/ } \\
\text { Agg }\end{array}$ & $\begin{array}{c}\text { W/ } \\
\text { C }\end{array}$ \\
\hline NC & NC & -- & -- & -- & 0.33 & 0.67 & 0.5 \\
\hline GPC & $16 \mathrm{M}$ & $16 \mathrm{M}$ & 2.5 & 0.55 & 0.38 & 0.62 & -- \\
\hline \multicolumn{7}{|c|}{ Mixes proportions kg/m3 } \\
\hline \\
\hline NC & 350 & -- & 600 & 1200 & -- & -- & 175 \\
\hline GPC & -- & 400 & 665 & 1086 & 157 & 63 & -- \\
\hline
\end{tabular}

$\mathrm{M}=$ Molarity, $\mathrm{NS}=$ Sodium silicate, $\mathrm{NH}=$ Sodium hydroxide, Sol=Solution, FA= Fly ash, S/Agg =Sand to aggregate ratio, $\mathrm{CA} / \mathrm{Agg}=\mathrm{Crushed}$ lime stone aggregate to aggregate ratio, $\mathrm{W}=\mathrm{Water}, \mathrm{C}=\mathrm{Cement}$ 


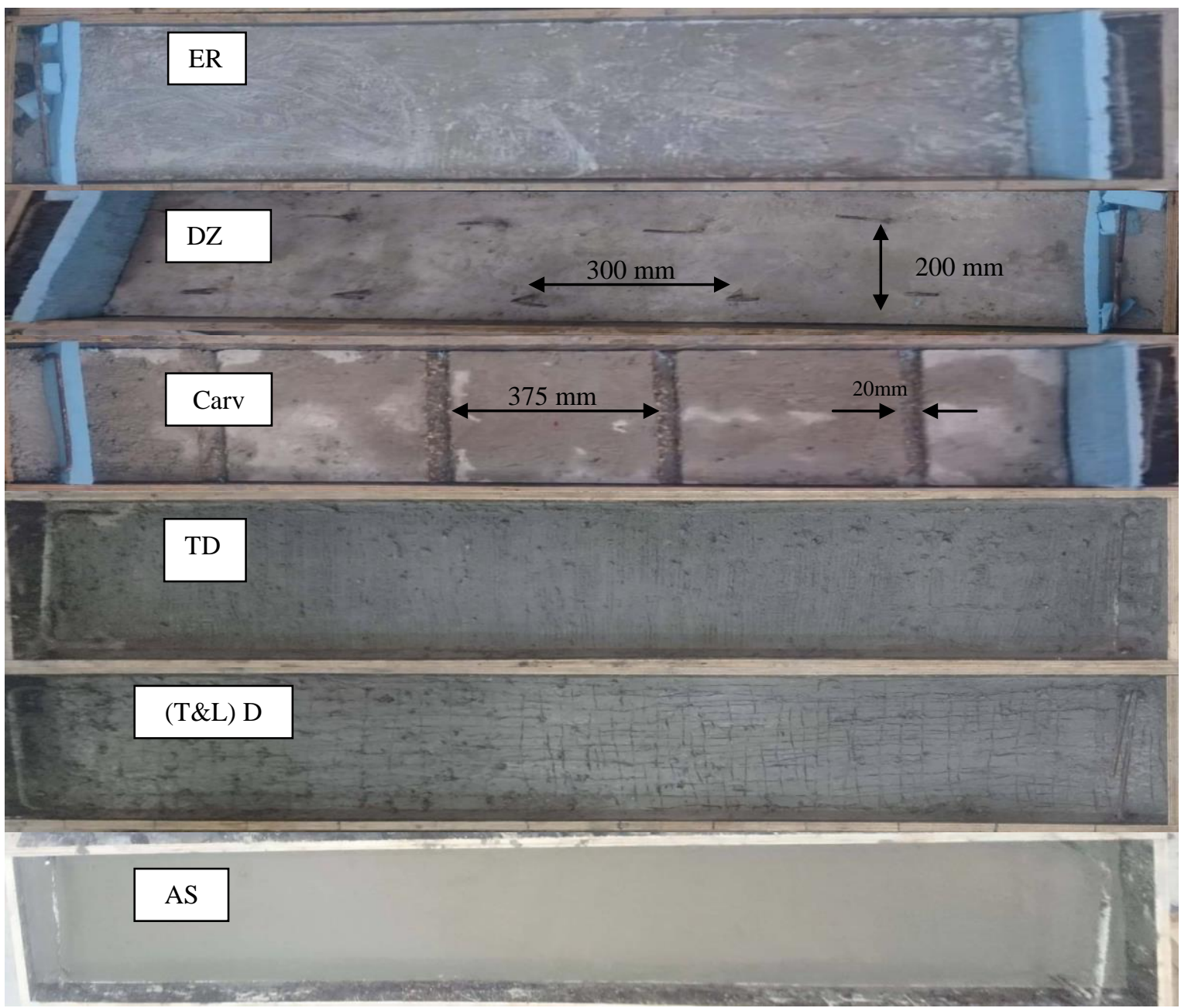

Fig. 1 Substrate specimens with different surface prebarations

Table 4: Different preparation techniques for substrate concrete surfaces

\begin{tabular}{|c|c|c|}
\hline $\begin{array}{c}\text { Slab } \\
\text { No }\end{array}$ & Slab ID* & Techniques \\
\hline 1 & ER & $\begin{array}{l}\text { Painting with epoxy resin on } \\
\text { the surface }\end{array}$ \\
\hline 2 & DZ & Dowels $8 \mathrm{~mm} \mathrm{Z} \mathrm{section}$ \\
\hline 3 & Carv & $\begin{array}{c}\text { Carving width } 2 \mathrm{~mm} \text { with } \\
\text { deep } 1 \mathrm{~mm}\end{array}$ \\
\hline 4 & TD & $\begin{array}{l}\text { Surface prepared with } \\
\text { steel brush in the } \\
\text { transverse direction }\end{array}$ \\
\hline 5 & (T\&L) D & $\begin{array}{l}\text { Surface prepared with steel } \\
\text { brush in both the longitudinal } \\
\text { and transverse directions }\end{array}$ \\
\hline 6 & AS & Smooth as cast \\
\hline 7 & Control & Smooth as cast \\
\hline
\end{tabular}

for slab No (7)

\section{Testing setup}

All slabs were tested after 3 months using

a Universal Testing Machine of $300 \mathrm{kN}$ capacity. The specimens were simply supported and subjected to a pair of point loads at a distance of $50 \mathrm{~cm}$ from both ends. One (LVDT) was placed at Figure 2 the end of the substrate slab and overlay to measure the interface slip. In addition, two dial gauges were fixed under the specimens in line with the mid span and the applied loads to evaluate the deflection of the specimens. To determine strain, two horizontal LVDTs and two strain gauges were established the specimens at different depths. The overall test layout is illustrated in Fig. 3. The load applied improved at each step and sustained until failure. The failure load was definite as a load that caused the specimen to fail in flexure or that caused failure at the interface between the substrate and overlay. Mid span deflections, strain values and interface slips were recorded for every load increment and will be discussed in the next part. 


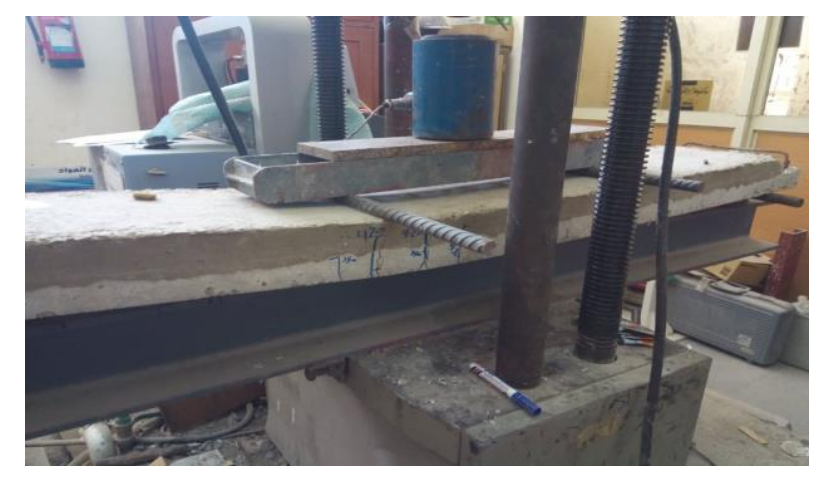

Fig. 2 Slab specimens test setup

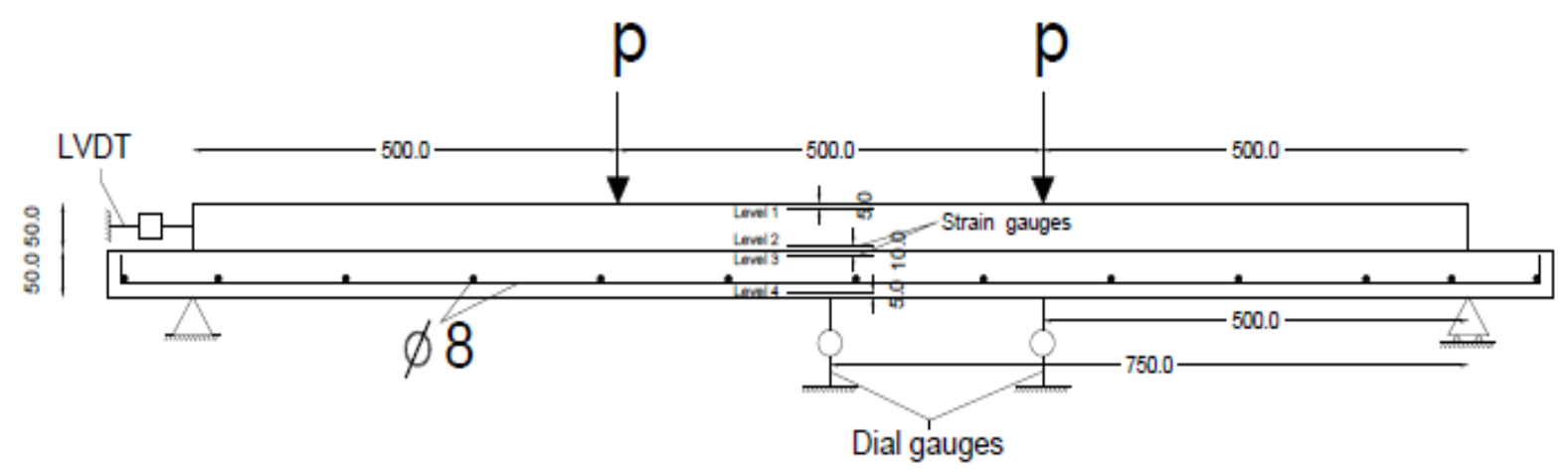

$-100.0$

1500.0

100.0

Fig. 3 Test layout

The ability of a member to deform without a large loss of its strength is known as ductility. One method of quantifying ductility is by the ductility factor (i.e., the displacement ductility index), which is defined by the ratio of the ultimate deflection to the deflection at yielding of the reinforcement [11].

Strain expresses the deformation of the specimen and can be calculated as modifies of the specimen's length divided by the specimen's original length. Interface slip at the mid span is measured by using a strain distribution diagram along the full depth of the specimens using the following description shown in Fig. 4. To calculate the interface slip, the gradient of the bottom is considered as the true strain gradient and is then applied for the overlay's strain gradient as illustrated in Fig. (4) c. The difference between $\mathrm{B}^{-}$ and $\mathrm{C}^{-}$shows the interface slip at the center of interface. The diagram with a lower gradient shows less interface slip and therefore the best monolithic behavior [11].

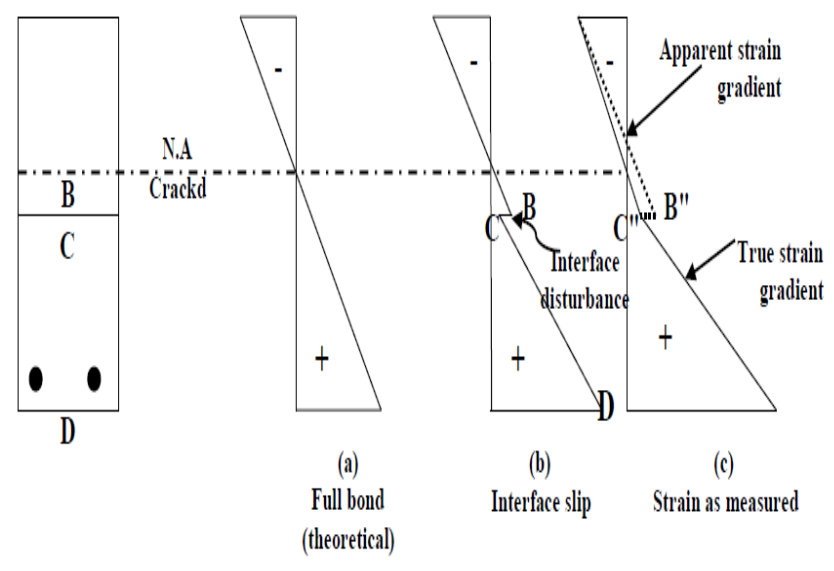

Fig. 4 Theoretical strain distribution diagram [11] 


\section{. Results and Discussions}

The characteristics of the specimens and concrete properties for both the substrate and overlay concrete slab after 28 days are shown on Table $\mathbf{5}$.

Table 5: Properties of substrate and overlay concrete slabs

\begin{tabular}{|c|c|c|c|c|c|}
\hline$\frac{\frac{\mathscr{U}}{\sigma}}{\sqrt{2}}$ & 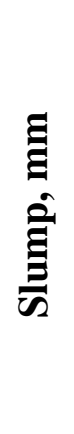 & 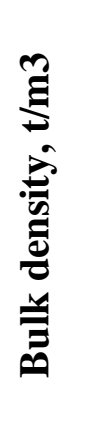 & 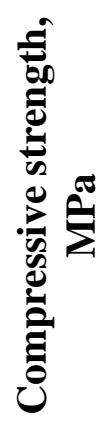 & 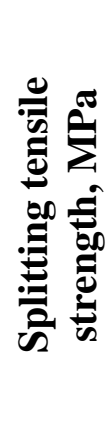 & 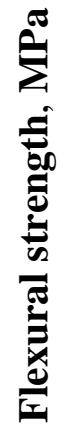 \\
\hline z & 60 & 2.37 & 33 & 2.5 & 4 \\
\hline U. & 100 & 2.36 & 61 & 4.2 & 8.5 \\
\hline
\end{tabular}

\section{Load Deflection Relationships}

The load versus mid-span deflection curves for all slab specimens are shown in Fig. 5. Originally, as the load enlarged, the deflection also raises linearly up to a certain load (i.e., the yield load), and after that point, the mid-span deflection varies non-linearly and achieves a maximum value. Further than the ultimate load point, the deflection starts rising substantially as the load increases.

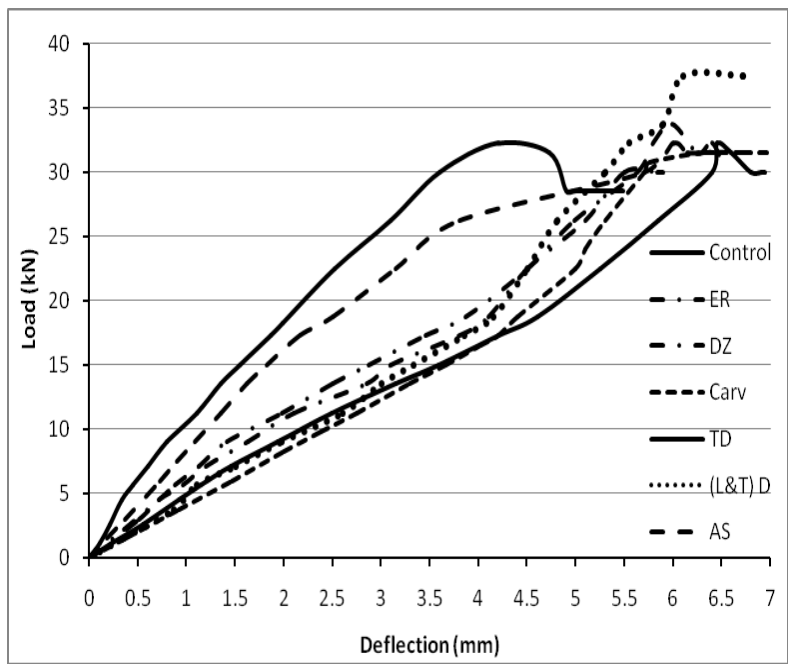

Fig. 5 Load versus the mid-span deflection

The values for the ductility index $(\Delta \mathrm{u} / \Delta \mathrm{y})$ as a measure of ductility were calculated and presented in Table 6.

Table 6: The test results at first crack, at yield and at failure load for different tested slabs

\begin{tabular}{|c|c|c|c|c|c|c|c|c|}
\hline Slab ID & $\begin{array}{l}\text { Pcr, } \\
\text { kN }\end{array}$ & $\begin{array}{l}\text { Py, } \\
\text { kN }\end{array}$ & $\begin{array}{l}\text { Pu, } \\
\text { kN }\end{array}$ & $\begin{array}{c}\Delta y, \\
\mathbf{m m}\end{array}$ & $\begin{array}{l}\Delta \mathrm{ul}, \\
\mathbf{m m}\end{array}$ & $\begin{array}{l}\Delta \operatorname{smax}, \\
\text { mm }\end{array}$ & $\begin{array}{c}\mathbf{i}= \\
\boldsymbol{\Delta u}_{\mathbf{u}} / \\
\boldsymbol{\Delta}_{\mathrm{y}}\end{array}$ & $\begin{array}{c}\text { Failure } \\
\text { mode }\end{array}$ \\
\hline Control & 9 & 18.75 & 32.25 & 4.2 & 6.4 & 6.95 & 1.52 & Comp. \\
\hline ER & 11.25 & 18.75 & 33.75 & 3.87 & 5 & 6.55 & 1.29 & Flexure \\
\hline $\mathrm{DZ}$ & 9 & 22.5 & 30 & 4.5 & 5.5 & 5.9 & 1.22 & Comp. \\
\hline Carv & 17.25 & 22.5 & 31.5 & 5 & 6.31 & 7.35 & 1.26 & Flexure \\
\hline TD & 11.25 & 26.25 & 32.25 & 3.1 & 4.2 & 5.49 & 1.35 & Flexure \\
\hline $\begin{array}{c}(\mathrm{T} \& \mathrm{~L}) \\
\mathrm{D}\end{array}$ & 15 & 18.75 & 37.5 & 4.15 & 5.49 & 6.8 & 1.32 & Flexure \\
\hline AS & 15 & 30 & 32.25 & 5 & 6 & 6.55 & 1.2 & Flexure \\
\hline
\end{tabular}

The ductility ratio for the test slabs ranged from 1.2 to 1.52. All the test slabs attained large deflection at failure. The increase of the yield load and its corresponding deflection resulted in this reduction of the ductility ratio, as defined in this investigation, in comparison to the control slab. As expected, the other slabs resulted in reduction in ductility ratio compared to reference control slab, the reductions in ductility ratio were $(67.13 \%) \mathrm{ER}$, (71.7\%) DZ, (69.1\%) Carv, (63.2\%)TD, (65.1\%) (T\&L) D and $(73.1 \%)$ AS, compared with control slab, respectively.

Load strain distribution

The load was applied regularly to all of the specimens, and strain along the mid-span was measured at various stages of loading. Figs. 6-12 
show the load versus strain curves of the specimens in 4 different levels that are defined in Fig 3. The strains at levels (2 and 3 ) were found by strain gauges fixed within the specimens. The strains at levels ( 1 and 4) were found by LVDTs fixed within the specimens. Negative and positive strains recorded at the top and bottom surface, respectively, show that the specimens are in sagging. As shown in the figures, the strain at the mid-span gradually increases during the test by increasing the applied load in all seven specimens. Significant changes in the slope of the curves indicate that multiple cracks started to occur at the mid-span. The maximum strain occurred in the tension region at level 4 , while the maximum strain occurred in the compression zone at level 1. When the specimens are close to their ultimate capacity, great bottom strain increments were examined for a small increment of load. The results of these figures will be used afterward to discover the interface slip and efficiency of the system.

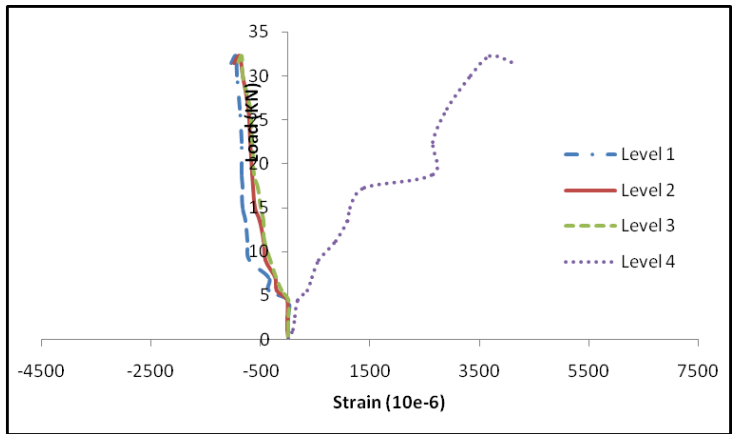

Fig. 6 Load versus strain for slab Control

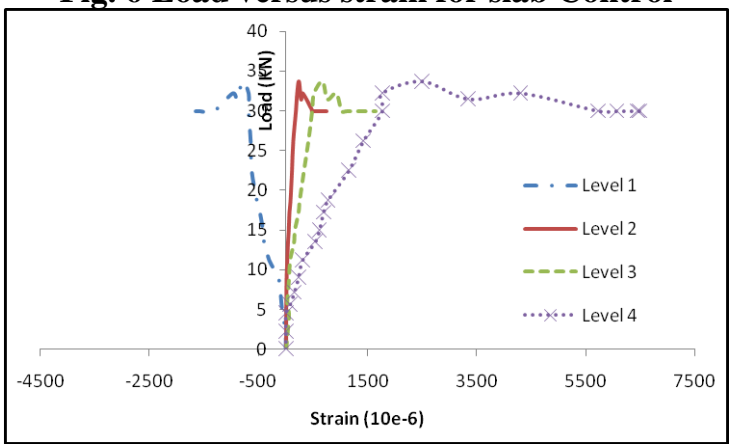

Fig. 7 Load versus strain for slab ER

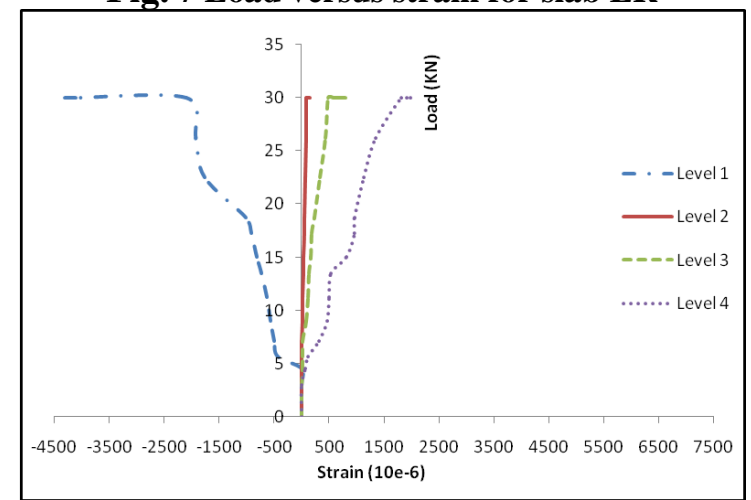

Fig. 8 Load versus strain for slab DZ

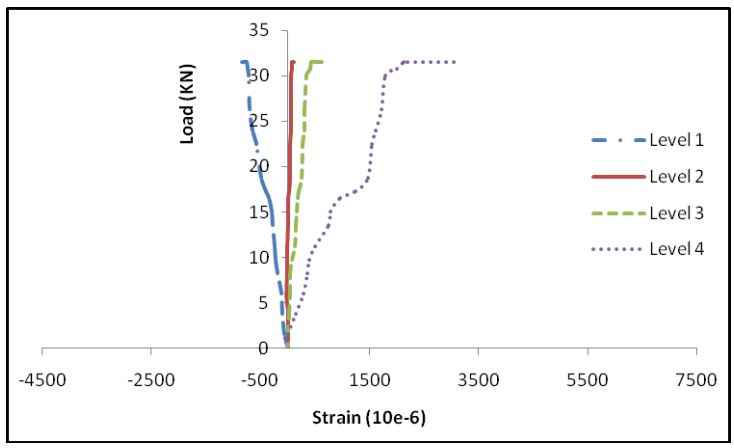

Fig.9 Load versus strain for slab Carv

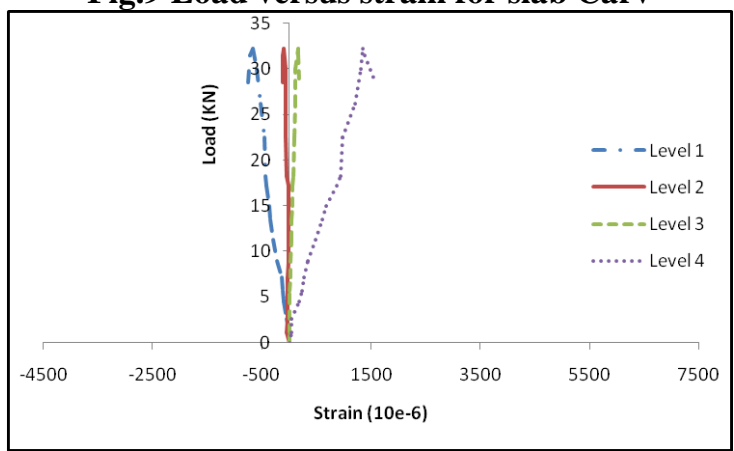

Fig.10 Load versus strain for slab TD

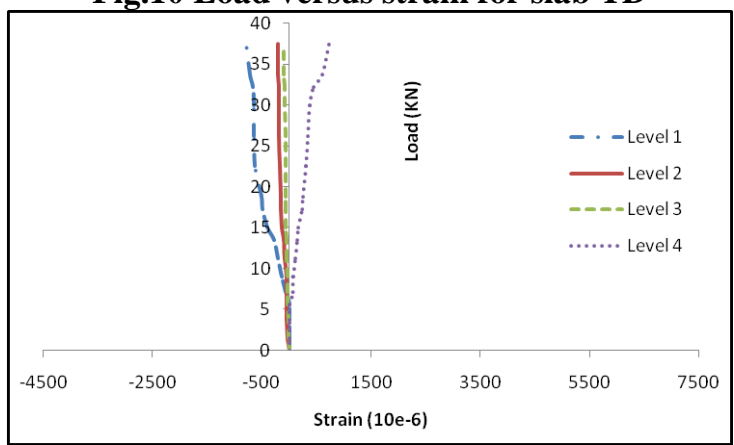

Fig.11 Load versus strain for slab (L\&T) D

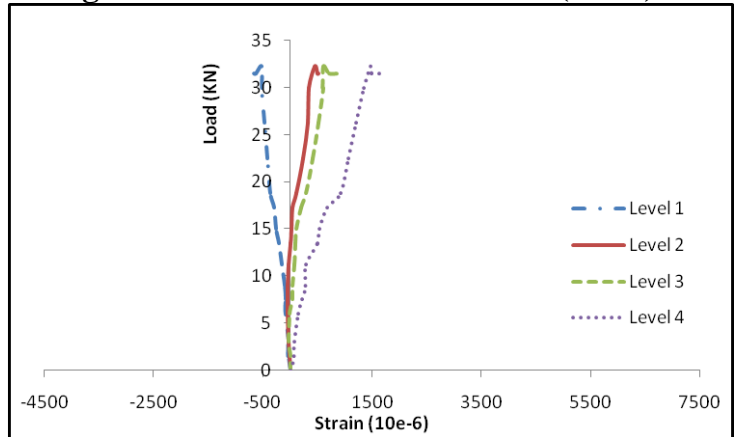

Fig.12 Load versus strain for slab AS 


\subsection{Interface slip}

When the compound members are subjected to a rising load, the primarily deform with the load at a very low speed. However, after the critical value of stress is achieved, the specimens endure a big deformation with fairly little increases in the practical load. This deformation is sourced by the slippage of the material along contact surfaces. Interface slip can be calculated by strain distribution diagram along the depth of slab. To estimate the bonding condition, slippage between the two layers has been calculated at the mid-span of all specimens. Strain distribution for all specimens at constant load $22.5 \mathrm{KN}$ shown in Fig.13.

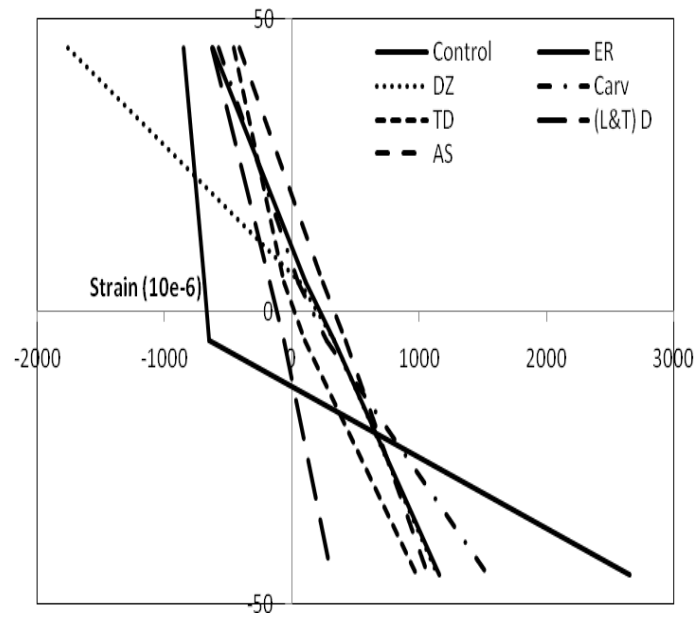

Fig. 13 Strain distribution for all specimens at constant load $22.5 \mathrm{kN}$

Strain distributions at full depth of slab (L\&T) D were calculated with strain gauges and LVDTs and are shown in Fig.14. The interface slip is zero in the case of equal strain gradients for both layers; the gradient changes if any slippage happens. Although, the interface slip is zero for slab (L\&T) D.

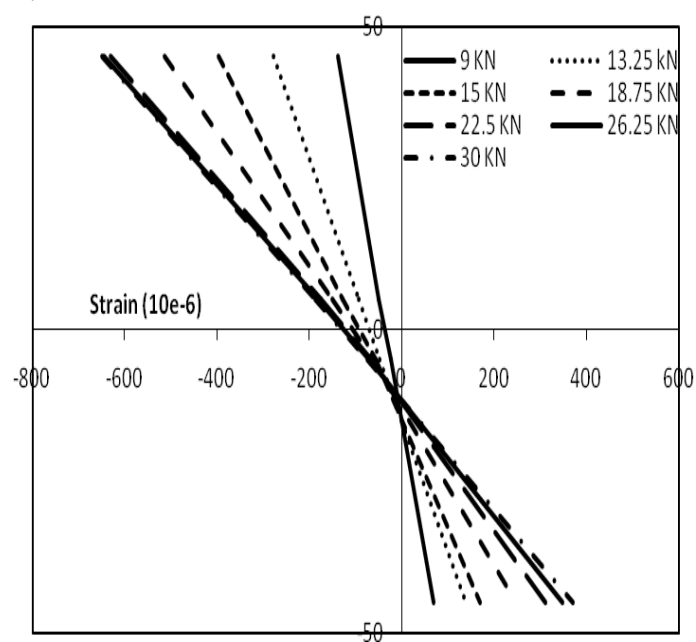

Fig. 14 Strain distribution for slab $(L \& T) D$
The test results explain that the strain gradient starts to modify for the substrate and the overlay by relating only $5.625 \mathrm{kN}$ load. However, the speed of transforms at this load is very fewer for slab (L\&T) D comparing to the other specimens. These changes grow to be more evident as the load is increased towards the ultimate load. The bottom strains are slightly larger than the top strains, demonstrating that the substrate slab is under tension while the overlay is in compression.

Interface slip for all specimens is shown in Fig. 15. Great slip at the interface is a mark of poor bonding between the overlay and substrate concretes. The biggest slip happened for slab control at $0.25 \mathrm{~mm}$, signifying poor bonding strength at the interface. This result proves that the normal concrete is estimated to setback overlay debonding. Slab (L\&T) D, with $0 \mathrm{~mm}$ of slippage, showed the best interface slip. Interface slippage was showed at all of the specimens; however, only slab failed at the interface was slab DZ.

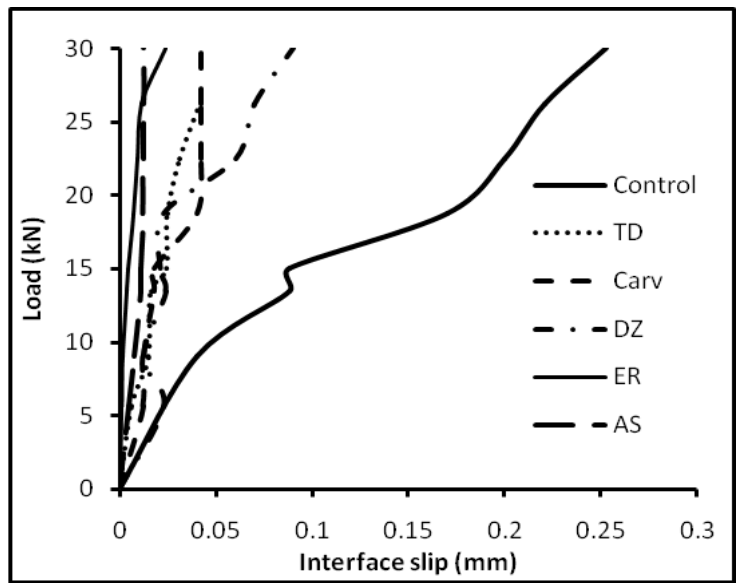

Fig. 15 Interface slip at the mid-span 


\section{CONCLUSIONS}

An experimental investigation to evaluate the flexural performance of reinforced substrate concrete slab with geopolymer concrete GPC topping related to different roughnesses of the substrate surface such as (painting with epoxy resin on the surface (ER), dowels $8 \mathrm{~mm} \mathrm{Z}$ section (DZ), carving $2 \mathrm{~mm}$ width and $1 \mathrm{~mm}$ deep (Carv), surface roughened in the transverse directions by a stiff brush (TD), surface roughened by a stiff brush in both the transverse and longitudinal directions (T\&L) D and as smooth as cast (AS). To examine the composite behavior of the specimens, load deflection, strain distribution and interface slip were measured throughout the experiments.

Based on the results and the analysis, the following conclusions could be drawn;

\section{REFERENCES}

[1] Turner L. K and Collins F. G, "Carbon dioxide equivalent (CO2-e) emissions: A comparison between geopolymer and OPC cement concrete", Construction and Building Materials Vol. 43, 2013,pp 125-130.

[2] Behfarnia K, Jon-nesari H and Mosharaf A , "The bond between repair materials and concrete substrate in marine environment", Asian journal of civil engineering (building and housing) vol. 6, 2005, pp 267-272.

[3] Beushausen $\mathrm{H}$, "The influence of concrete substrate preparation on overlay bond strength", Magazine of Concrete Reasearch, Vol. 11, 2010, pp 845-852.

[4] Phoo-ngernkham T, Maegawa A, Mishima N, Hatanaka S and Chindaprasirt P, "Effects of sodium hydroxide and sodium silicate solutionson compressive and shear bond strengths of FA-GBFS geopolymer", Construction and Building Materials Vol. 91, 2015, pp 1-8.

[5] Zhang Z, Provis J. L, Reid A and Wang H, "Mechanical, thermal insulation, thermal resistance and acoustic absorption properties of geopolymer foam concrete", Cement \& Concrete Composites Vol. 62, 2015, pp 97105
1. Ductile performance of slab depends not only on adding GPC to the topping but mainly on the type of interface roughness.

2. The slabs resulted in reduction in ductility ratio compared to reference control slab, the reductions were $(67.13 \%) \mathrm{ER},(71.7 \%) \mathrm{DZ}$, ( 69.1\%) Carv, (63.2\%)TD, (65.1\% ) (T\&L) D and $(73.1 \%)$ AS compared with control slab, respectively.

3. The biggest slip happened for control slab (NC/RC) at $0.25 \mathrm{~mm}$, signifying poor bonding strength at the interface.

4. Slab that the surface roughened by a stiff brush in both the transverse and longitudinal directions, with zero $\mathrm{mm}$ of slippage, showed the best interface slip.

[6] Sarker P. K, "Bond strength of reinforcing steel embedded in fly ash-based geopolymer", Materials and Stuctures Vol. 44, 2011, pp 1021-1030.

[7] EN 196-1:2016 "Methods of Testing Cement Part 1: Determination of strength"

[8] ES 4756-1: Cement Part:( 1) "Composition, specifications and conformity criteria for common cements"

[9] ECP 203-2007 " Egyptian Code for Design and Construction of Reinforced Concrete Structures, Annual Book for Testing of materials, Part 3, Ministry of Housing and Urbanization, Housing and Building Research Center, Cairo, Egypt.

[10] ASTM C33 / C33M - 18 "Standard specification for concrete aggregates"

[11] Farnoud R. M, Suhaimi A. B, Izni S. I., Abdul K. M, Bahram .M, "Flexural performance of a precast concrete slab with steel fiber concrete topping" Construction and Building Materials Vol. 75 (2015), pp 112-120.

Tech. Rep. No. 54, 1973. 